\title{
Perbedaan Prestasi Belajar Bahasa Inggris Siswa Ditinjau dari Tipe Kepribadian Introvert dan Extrovert
}

\author{
Balqis Husain ${ }^{1}$,I.ibrahim ${ }^{2}$ \\ ${ }^{1}$ Program Studi Pendidikan Bahasa Inggris Fakultas Keguruan dan Ilmu Pendidikan \\ Universitas Pasifik Morotai \\ balqishusain.bh@gmail.com \\ ${ }^{2}$ Program Studi Pendidikan Bahasa Inggris Fakultas Keguruan dan Ilmu Pendidikan \\ Universitas Muhammadiyah Sorong \\ iibrahim080988@gmail.com
}

\begin{abstract}
Abstrak
Penelitian ini bertujuan untuk mengetahui perbedaan prestasi belajar bahasa inggris siswa ditinjau dari tipe kepribadian introvert dan extrovert pada siswa SMA di Kabupaten Pulau Morotai. Desain penelitian ini menggunakan pendekatan Kualitatif dengan metode deskriptif. Populasi dalam penelitian ini adalah siswa SMA di Kabupaten Pulau Morotai, yang tersebar lima kecamatan. proses penentuan sampling dilakukan dengan menggunakan table Krejchie-Morgan, maka sampel yang digunakan dalam penelitian ini berjumlah 174 dari jumlah keseluruhan populasi adalah 323 siswa. Intrumen yang digunakan dalam penelitian ini terdiri dari dua instrument yaitu:1) Questioner untuk mengukur tipe kepribadian siswa. 2) Dokumentasi hasil belajar siswa selama satu semester. Teknik analisis data yang digunakan dalam penelitian ini adalah analisis deskriptif. Hasil menunjukkan bahwa 10\% siswa dengan tipe kepribadian introvert maupun extrovert belum mampu mencapai criteria minimum KKM pada mata pelajaran bahasa inggris. Siswa dengan kepribadian introvert maupun extrovert tidak memiliki perbedaan terhadap capaian hasil belajar pada mata pelajaran Bahasa Inggris.
\end{abstract}

Kata Kunci: Prestasi belajar, introvert, extrovert

Abstract-This research aims to know the differences in English learning achievement seen from introvert and extrovert personality types toward high school students of Morotai. Design of this research used qualitative and focused to the descriptive method. Population of this research was high school students in the regency of Morotai Island that separated in the 5 sub-district. Sampling technique of this research used Krechie Morgan's Table. Thus, sample of this research was 174 students and population was 323 students. Instrument that was used in this research were 2 instruments, they are 1) questionnaire; to measure the students personality types. 2) Documentation; to know the students' English learning achievement for one semester. Data analyze in this research used descriptive analyze. Result showed that $10 \%$ students with introvert and extrovert personality types unable to get minimum criteria of KKM to the English lesson. The students with introvert and extrovert personality types had no different toward English learning achievement.

Keywords: Learning achievement, introvert Extrovert 


\section{PENDAHULUAN}

Kepribadian merupakan faktor terpenting yang mempengaruhi prestasi belajar seseorang dalam pembelajaran dikelas. Menurut Azwar (2008:51) ada dua faktor yang mempengaruh prestasi belajar siswa yaitu faktor internal dan faktor external, faktor internal meliputi faktor fisik dan faktor psikologis. Faktor fisik seperti penglihatan dan pendengaran sedangkan faktor psikologis seperti motivasi, minat belajar, bakat, intelegensi, sikap dan kesehatan mental. Faktor eksternal meliputi faktor fisik dan faktor sosial. Faktor fisik meliputi kondisi tempat belajar, sarana dan prasarana, materi pelajaran serta lingkungan belajar, sedangkan faktor sosial menyangkut dukungan sosial dan pengaruh budaya. Faktor kepribadian memberikan pengaruh dalam pencapaian belajar karena kepribadian termasuk dalam faktor psikologis. Nilawati dan Bimo (2010:27) Faktor penting yang di gunakan dalam pencapaian prestasi belajar salah satunya adalah faktor psikologis, karena faktor psikologis merupakan predictor penting bagi kinerja kognitif dan faktor psikologis memainkan peran penting didalam kesuksesan akademik. Lusiana et.al (2009: 59) menambahkan bahwa faktor utama yang menentukan keberhasilan seorang pelajar dalam menyelesaikan pendidikan antara lain kualitas input siswa itu sendiri, yang meliputi tingkat intiligensi, kepribadian, motivasi, kesehatan fisik, minat, dan gaya belajar. Faktor lain adalah proses belajar mengajar yang didukung antara lain oleh pengajar, fasilitas fisik, pembiayaan, informasi, kurikulum, serta lingkungan sosial pelajar tersebut.

Feist \& Feist (2010:117) menyatakan bahwa sifat kepribadian memiliki peranan penting terhadap kesuksesan di sekolah dan hasil-hasil jangka panjang. Bahkan kepribadian juga dapat mempengaruhi keadaan jiwa yang dialami seseorang. Menurut Ulya (2016: 5) dalam penggunakan metode, strategi, dan teknik pembelajaran di dalam kelas, seorang guru wajib mempertimbangkan tipe kepribadian para peserta didik. Hal ini disebabkan karena setiap peserta didik memiliki tipe kepribadian yang berbeda-beda. Kepribadian siswa merupakan poin yang menjadi pertimbangan dalam penentuan kelulusan hasil belajar. Kelulusan dan 
keberhasilan belajar peserta didik tidak hanya ditentukan oleh nilai akademik tetapi juga karakter yang dimiliki siswa bahkan Penilaian kepribadian diharapkan tidak hanya menciptakan lulusan yang cerdas secara akademik tetapi juga mental dan spiritual sehingga generasi masa depan akan memiliki etos kerja yang baik, akhlak mulia, memiliki jiwa kepemimpinan dan menghindari perilaku negatif (Wijaya dan Indriana, 2013:5).

Menurut Hawari (2008:27) Kepribadian merupakan karakteristik seseorang yang menyebabkan munculnya konsistensi perasaan, pemikiran dan perilaku. Kepribadian adalah pola dari persepsi, cara mengadakan hubungan dan berfikir yang menetap tentang lingkungan dan diri sendiri dan dinyatakan secara luas didalam konteks kehidupan social dan hubungan pribadi seseorang. Kepribadian yang dimiliki manusia bersifat unik dan konsisten sehingga dapat digunakan sebagai alat ukur untuk membedakan antara individu satu dengan yang lain. Komang dan Yohanes (2013:132) menggolongkan tipe kepribadian kedalam dua tipe yaitu tipe kepribadian introvert dan ekstrovert, penggolongan tipe kepribadian ekstrovert dan introvert didasarkan pada perbedaan interaksi, kebiasaan, respon, serta komunikasi tiap-tiap individu dalam bersosialisasi dengan lingkungan disekitarnya. Selain itu, tipe kepribadian juga menjelaskan posisi kecenderungan individu yang berhubungan dengan reaksi atau tingkah lakunya.

Penggolongan tipe kepribadian ekstrovert dan introvert dapat menggambarkan pola komunikasi dan interaksi sosial setiap individu. Menurut Yusuf dan Nurihsan (2007) ciri-ciri orang dengan kepribadian introvert yaitu lebih berorientasi pada dirinya sendiri, dan dipengaruhi oleh dunia objective, orang dengan kepribadian introvert mudah mengalami kecemasan, lebih tertutup dan susah beradaptasi. Sedangkan ciri orang kepribadian extrovert di pengaruhi oleh dunia subjective orang dengan ciri kepribadian extrovert lebih mudah bergaul, agresif, spontan dan kurang sabar. Pada saat berkomunikasi dan berinteraksi dengan orang lain, individu dengan tipe kepribadian ekstrovert adalah individu dengan karakteristik utama yaitu mudah bergaul, impulsif, tetapi juga sifat gembira, aktif,cakap dan 
optimis serta sifat-sifat lain yang mengindikasikan penghargaan atas hubungan dengan orang lain, sedangkan individu dengan kepribadian introvert adalah individu yang memiliki karakteristik yang berlawanan dengan tipe kepribadian ekstrovert, yang cenderung pendiam, pasif, tidak mudah bergaul, teliti, pesimis, tenang dan terkontrol (Feist \& Feist, 2010).

Secara umum, individu yang tergolong introvert lebih berorientasi pada stimulus internal dibandingkan dengan individu yang tergolong ekstrovert. Individu yang tergolong introvert akan lebih memperhatikan pikiran, suasana hati dan reaksireaksi yang terjadi dalam diri mereka. Hal ini membuat individu yang tergolong introvert cenderung lebih pemalu, memiliki control diri yang kuat, dan memiliki keterpakuan terhadap hal-hal yang terjadi dalam diri mereka serta selalu berusaha untuk mawas diri, tampak pendiam, tidak ramah, lebih suka menyendiri, dan mengalami hambatan pada kualitas tingkah laku yang ditampilkan. Berdasarkan penelitian yang dilakukan oleh Dimitru dkk tentang The Relationship Between Stress and Personality Factors bahwa individu dengan type kepribadian introvert lebih rentan mengalami stres dibandingkan dengan invididu dengan orientasi kepribadian ekstrovert (Dimitru, 2012). Sedangkan individu yang tergolong ekstrovert cenderung tampak lebih bersemangat, mudah bergaul, terkesan impulsif dalam menampilkan tingkah laku. Individu yang tergolong ekstrovert merupakan seseorang yang berani melanggar aturan, memiliki rasa toleransi yang lebih tinggi terhadap rasa sakit, dan lebih mudah terlibat dalam suatu relasi (Komang dan Yohanes, 2013).

Siswa SMA yang berada di Kabupaten Pulau Morotai merupakan individu yang memiliki kepribadian yang berbeda satu sama lain, perbedaan tipe kepribadian siswa yang introvert maupun extrovert tidak hanya akan mempengauhi interaksi sosial akan tetapi mempengaruhi pencapaian prestasi belajar khususnya mata pelajaran Bahasa Inggris, Berdasarkan latar belakang masalah diatas maka peneliti tertarik untuk meneliti mengenai perbedaan prestasi belajar bahasa inggris siswa ditinjau dari tipe kepribadian introvert dan extrovert. 


\section{METODE PENELITIAN}

Penelitian ini dilaksanakan selama 7 bulan dan dilakukan di Kabupaten Pulau Morotai yang terdiri atas 5 kecamatan yaitu Kecamatan Morotai Selatan, Kecamatan Morotai Jaya, kecamatan Morotai Selatan Barat, Kecamatan Morotai Utara dan Kecamatan Morotai Timur. Sekolah yang dipilih untuk mewakili penelitian ini adalah SMA yang berada di 5 kecamatan tersebut.

Peneliti menetapkan populasi yang menjadi objek dalam penelitian ini adalah siswa SMA di Kabupaten Pulau Morotai Sekolah yang dipilih untuk mewakili penelitian ini adalah SMA yang berada di Kabupaten Pulau Morotai, yaitu SMA Muhammadiyah 3 Pulau Morotai, SMA Negeri 6 Pulau Morotai, SMA Muhammadiyah 4 Pulau Morotai, SMA Negeri 1 Pulau Morotai, SMA Negeri 2 Pulau Morotai, dan SMA Negeri 4 Pulau Morotai. Jumlah populasi yang tersebar di enam SMA tersebut sebanyak 323 siswa. Pengambilan sampel ini menggunakan tabel Krejchie-Morgan dengan tingkat kesalahan 5\%. Maka Sampel pada penelitian ini berjumlah 174 .

Penelitian ini menggunakan pendekatan kualitatif. Metode penelitian yang digunakan oleh peneliti pada penelitian ini adalah deskriptif. Berikut skema penelitian yang dilaksanakan.

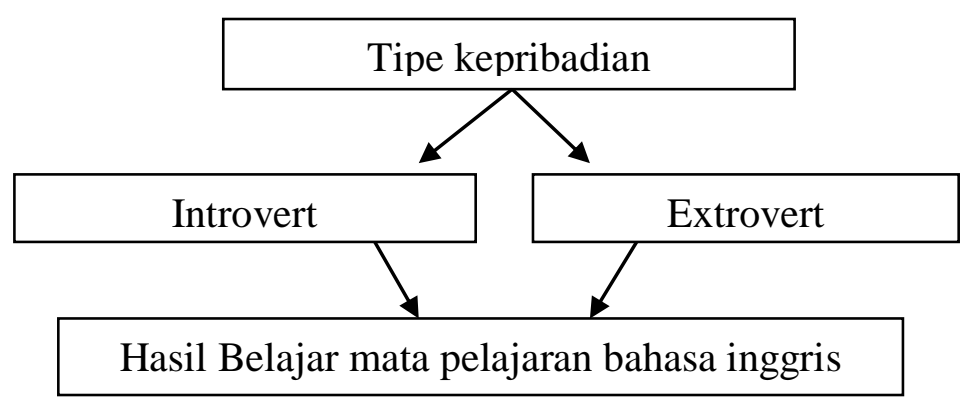

Gambar 1. Design Penelitian

Penelitian ini menggunakan 2 alat ukur penelitian, yaitu questioner dan dokumentasi. Dokumentasi dilakukan untuk mengetahui pencapaian prestasi akademik pada mata pelajaran bahasa Inggris selama 1 semester yang dibuktikan 
dengan hasil laporan akhir selama satu semester pada tahun ajaran 2017/2018. Alat ukur yang digunakan untuk mengetahui kepribadian seseorang dilakukan dengan menyebarkan angket kepribadian berdasarkan alat ukur kepribadian (personality test). Eysenck Personality Inventory (EPI) adalah sebuah tes untuk mengungkap type kepribadian individu apakah extrovert dan atau introvert dengan pilihan "ya" dan “tidak" (Asriasa, 2010). EPI terdiri atas 32-item dan hanya difokuskan pada dimensi extrovert-introvert sesuai dengan permasalahan yang akan diteliti.

Tabel 1. Kisi-kisi Alat Ukur Eysenck Personality Inventory (EPI)

\begin{tabular}{|c|c|c|c|c|}
\hline Dimensi & $\begin{array}{c}\text { Sub } \\
\text { Dimensi }\end{array}$ & Indikator & $\begin{array}{c}\text { No Item } \\
\text { Pertanyaan }\end{array}$ & $\begin{array}{l}\text { Jumlah } \\
\text { Item }\end{array}$ \\
\hline \multirow[t]{7}{*}{$\begin{array}{l}\text { Extrovert } \\
\text { introvert }\end{array}$} & Activity & $\begin{array}{ll}\text { - } & \text { Aktivitas fisik } \\
\text { - } & \text { Kecepatan dalam bergerak }\end{array}$ & $\begin{array}{l}1,2,8,12, \\
23,27,28, \\
29\end{array}$ & 8 \\
\hline & Sociability & $\begin{array}{l}\text { - Kesukaan mencari teman, } \\
\text { bertemu dengan banyak } \\
\text { orang }\end{array}$ & $\begin{array}{l}3,4,6,11, \\
13\end{array}$ & 5 \\
\hline & $\begin{array}{l}\text { Risk } \\
\text { Taking }\end{array}$ & - $\quad$ keberanian mengambil resiko & 19,24 & 2 \\
\hline & $\begin{array}{l}\text { Impulsive } \\
\text { ness }\end{array}$ & $\begin{array}{ll}\text { - } & \text { Kecenderungan bertindak } \\
\text { secara mendadak } \\
\text { - } & \text { kurang menggunakan } \\
\text { pertimbangan }\end{array}$ & $\begin{array}{l}16,26,32, \\
30\end{array}$ & 4 \\
\hline & $\begin{array}{l}\text { Expressiv } \\
\text { eness }\end{array}$ & $\begin{array}{ll}\text { - } & \text { Pernyataan perasaan } \\
\text { - } & \text { kemauan memperlihatkan } \\
& \text { emosi secara terbuka }\end{array}$ & $\begin{array}{l}5,7,9,15 \\
18,21,22\end{array}$ & 7 \\
\hline & $\begin{array}{l}\text { Reflective } \\
\text { ness }\end{array}$ & - $\quad$ Kedalaman berfikir & $\begin{array}{l}10,14,17, \\
31\end{array}$ & 4 \\
\hline & $\begin{array}{l}\text { Responsib } \\
\text { ility }\end{array}$ & 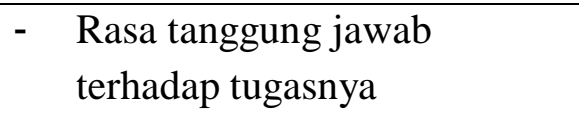 & 20,25 & 2 \\
\hline \multicolumn{2}{|c|}{ Jumlah Total Item } & & & 32 \\
\hline
\end{tabular}

(Sumber: Baharudin, 2012)

Setiap pertanyaan dalam kuisioner mengandung indikasi sebagai berikut: 
a) ae untuk pertanyaan affiliative extraversion

b) ne untuk pertanyaan non affiliative extraversion

Uji validitas pada penelitian ini dilakukan dengan menghitung koefisien reprodusibilitas dan koefisien skalabilitasnya. Sebelum mencari nilai koefisien reprodosibilitas, terlebih dahulu mencari nilai eror, dengan syarat penerimaan nilai koefisien reprodusibiltas yaitu apabila koefisien reprodusibiltas memiliki nilai $>0,90$ dan syarat penerimaan nilai koefisien skalabilitas yaitu apabila koefisien skalabilitas memiliki nilai $>0,60$. Adapun runtutan rumusnya sebagai berikut;

Rumus Koefisien Reprodusibilitas:

$\mathrm{Kr}=1-(\mathrm{e} / \mathrm{n})$

$\mathrm{e}=\mathrm{Jumlah}$ kesalahan/ nilai error

$\mathrm{n}=$ jumlah pernyataan dikali jumlah responden

Rumus Koefisien Skalabilitas:

$\mathrm{Ks}=1-(\mathrm{e} / \mathrm{x})$

$\mathrm{e}=$ jumlah kesalahan/nilai error

$\mathrm{x}=0,5$ (\{jumlah pernyataan dikali jumlah responden $\}-$ jumlah jawaban "ya").

\section{HASIL DAN PEMBAHASAN}

Tabel 2. Pengujian validitas Angket Kepribadian dengan $\mathrm{Kr}$ dan $\mathrm{Ks}$

\begin{tabular}{cc}
\hline Koefisian Reprodusibilitas (Kr) & Koefisien Skalabilitas (Ks) \\
\hline 0.9833 & 0.76471 \\
\hline
\end{tabular}

Dalam penghitungan ini terlihat bahwa $\mathrm{Kr}=0.98$, sehingga berdasarkan kategori koefisien validitas Guilford bahwa kuisioner dapat disimpulkan baik untuk digunakan dalam penelitian apabila syarat penerimaan nilai koefisien reprodusibilitas memiliki nilai >0, 90 dan syarat penerimaan nilai koefisien skalabilitas memiliki nilai $>0,60$. Adapun dalam penghitungan koefisien skalabilitas diperoleh hasil $\mathrm{Ks}=0.76$, 
sehingga disimpulkan bahwa kuisioner dapat disimpulkan baik untuk digunakan dalam penelitian.

Tabel 3. Penggolongan Tipe kepribadian introvert dan Ekstrovert

\begin{tabular}{ccccc}
\hline No & Nama Sekolah & $\begin{array}{c}\text { Siswa dengan } \\
\text { kepribadian } \\
\text { Introvert }\end{array}$ & $\begin{array}{c}\text { Siswa dengan } \\
\text { kepribadian } \\
\text { Extrovert }\end{array}$ & Jumlah \\
\hline 1 & SMA Negeri 1 Pulau Morotai & 6 & 51 & 57 \\
\hline 2 & SMA Negeri 2 Pulau Morotai & 2 & 15 & 17 \\
\hline 3 & SMA Negeri 4 Pulau Morotai & 7 & 26 & 33 \\
\hline 4 & SMA Negeri 6 Pulau Morotai & 7 & 8 & 15 \\
\hline 5 & SMA Muhammmadiyah 3 & 10 & 10 & 20 \\
\hline 6 & SMA Muhammmadiyah 4 & 8 & 24 & 32 \\
\hline & Total & $\mathbf{4 0}$ & $\mathbf{1 3 4}$ & $\mathbf{1 7 4}$ \\
\hline
\end{tabular}

Tabel tersebut menjelaskan bahwa jumlah keseluruhan siswa dari 6 sekolah sebanyak 174 siswa, dimana 76\% didominasi oleh siswa dengan tipe kepribadian extrovert sedangkan $24 \%$ sisanya didominasi oleh siswa dengan tipe kepribadian introvert, dengan perbandingan 1 dari 3 siswa dalam kelas memiliki kepribadian introvert.

Tabel 4. Capaian KKM pada Mata Pelajaran Bahasa Inggris

\begin{tabular}{ccccc}
\hline No & Nama Sekolah & $\begin{array}{c}\text { Tuntas } \\
\text { KKM }\end{array}$ & $\begin{array}{c}\text { Tidak Tuntas } \\
\text { KKM }\end{array}$ & Jumlah \\
\hline 1 & SMA Negeri 1 Pulau Morotai & 56 & 1 & 57 \\
\hline 2 & SMA Negeri 2 Pulau Morotai & 10 & 7 & 17 \\
\hline 3 & SMA Negeri 4 Pulau Morotai & 31 & 1 & 32 \\
\hline 4 & SMA Negeri 6 Pulau Morotai & 11 & 4 & 15 \\
\hline 5 & SMA Muhammmadiyah 3 & 16 & 4 & 20 \\
\hline 6 & SMA Muhammmadiyah 4 & 32 & 1 & 33 \\
\hline & Total & $\mathbf{1 5 6}$ & $\mathbf{1 8}$ & $\mathbf{1 7 4}$ \\
\hline
\end{tabular}

Berdasarkan pada tabel 1.8 dapat dilihat bahwa siswa yang tidak mencapai Kriteria Ketuntasan Minimum (KKM) hanya mencapai10\%, sedangkan rerata siswa di enam sekolah secara keseluruhan dapat mencapai Kriteria Ketuntasan Minimum 
pada mata pelajaran Bahasa Inggris. hal ini dapat dilihat dari 174 siswa yang mencapai KKM sebanyak 156 siswa dengan persentase $90 \%$.

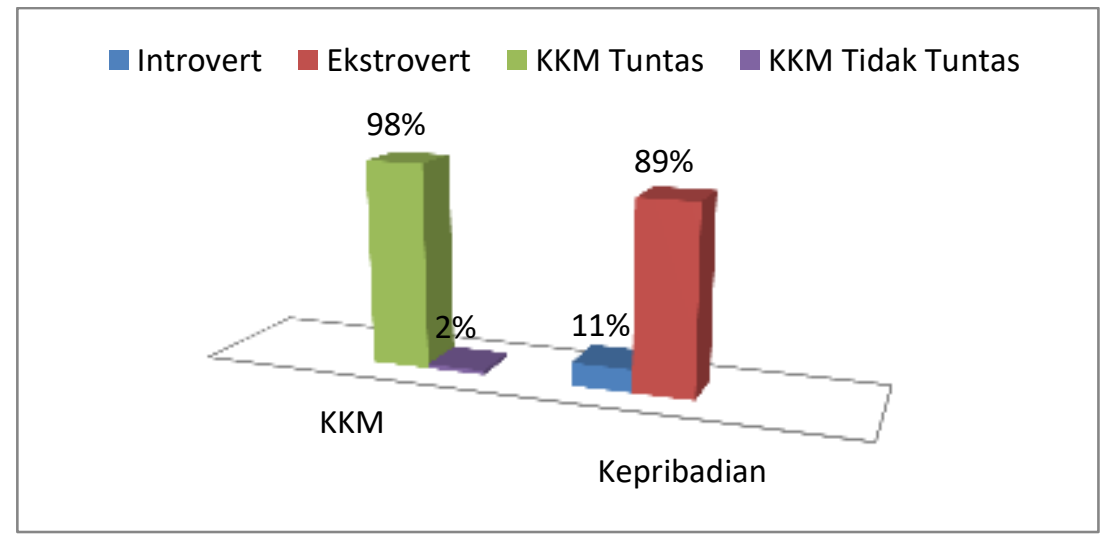

Gambar 2. Persentase Capaian KKM Siswa dengan Tipe Kepribadian Introvert dan Extrovert pada Siswa SMA N 1 Pulau Morotai

Pada gambar 1.3 dapat disimpulkan bahwa siswa yang memiliki kepribadian introvert sebanyak 6 siswa dari 57 siswa yang dijadikan sample pada penelitian. Akan tetapi yang mencapai Kriteria ketuntasan minimum (KKM) sebanyak 56 siswa baik dari kategori kepribadian introvert maupun ekstrovert dan hanya 1 siswa yang tidak mencapai KKM nasional.

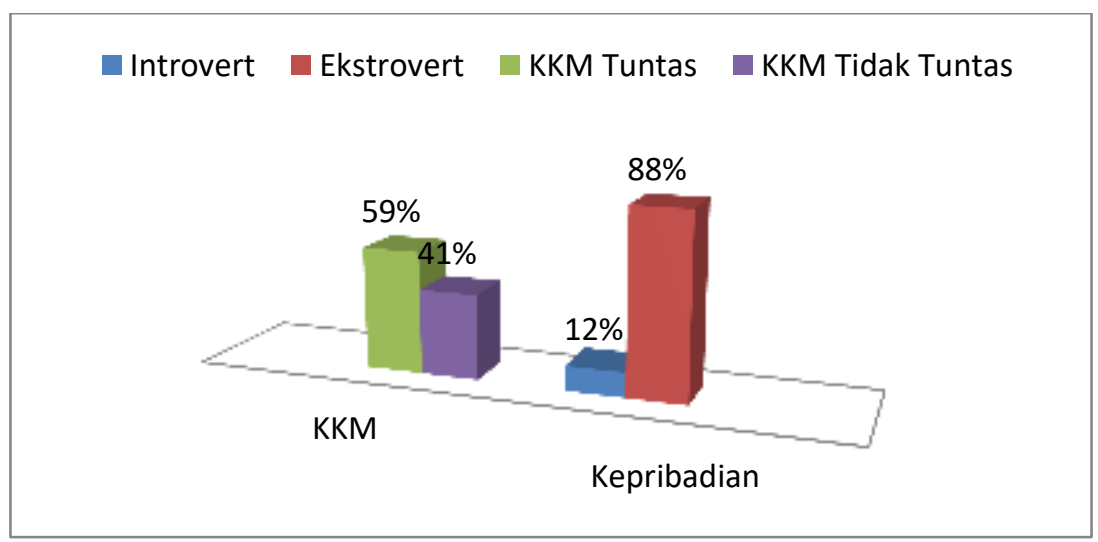

Gambar 3. Persentase Capaian KKM Siswa dengan Tipe Kepribadian Introvert dan Extrovert pada Siswa SMA N 2 Pulau Morotai 
Gambar diatas memaparkan bukti bahwa dari 17 siswa hanya 10 siswa yang mampu mencapai KKM nasional sedangkan 7 siswa lainnya tidak dapat mencapai KKM pada mata pelajaran Bahasa Inggris. Dimana pada kelas ini tersebar siswa dengan kepribadian introvert sebanyak 2 siswa dan 15 siswa lainnya memiliki kepribadian Extrovert.

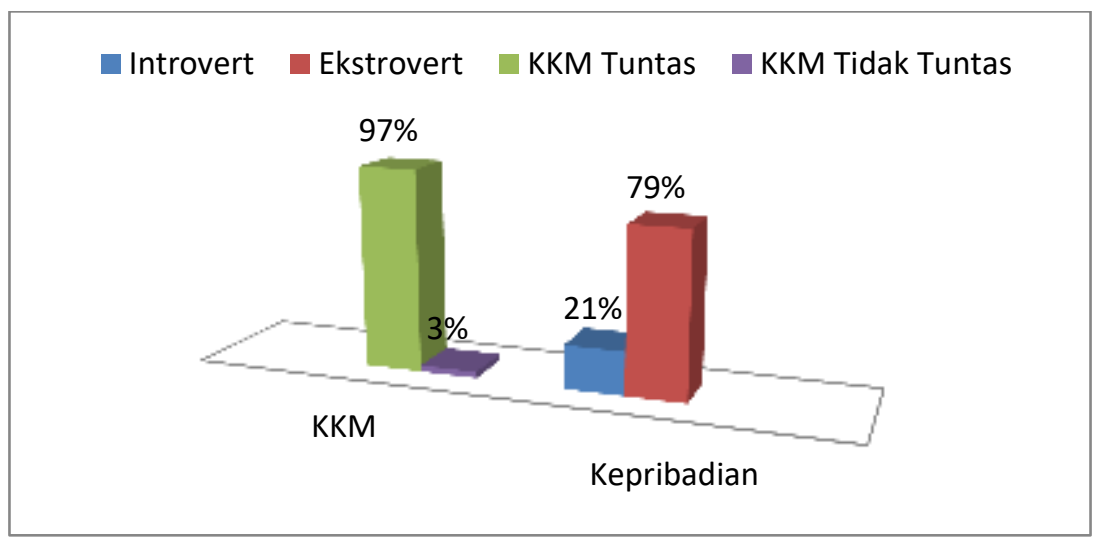

Gambar 4. Persentase Capaian KKM Siswa dengan Tipe Kepribadian Introvert dan Extrovert pada Siswa SMA N 4 Pulau Morotai

Dari gambar diatas dapat diuraikan bahwa dari 32 siswa hanya terdapat 1 siswa yang tidak dapat menuntaskan Kriteria Ketuntasan Minimum dan terdapat 26 siswa dengan kepribadian extrovert sedangkan 7 siswa lainnya memiliki kepribadian introvert. 


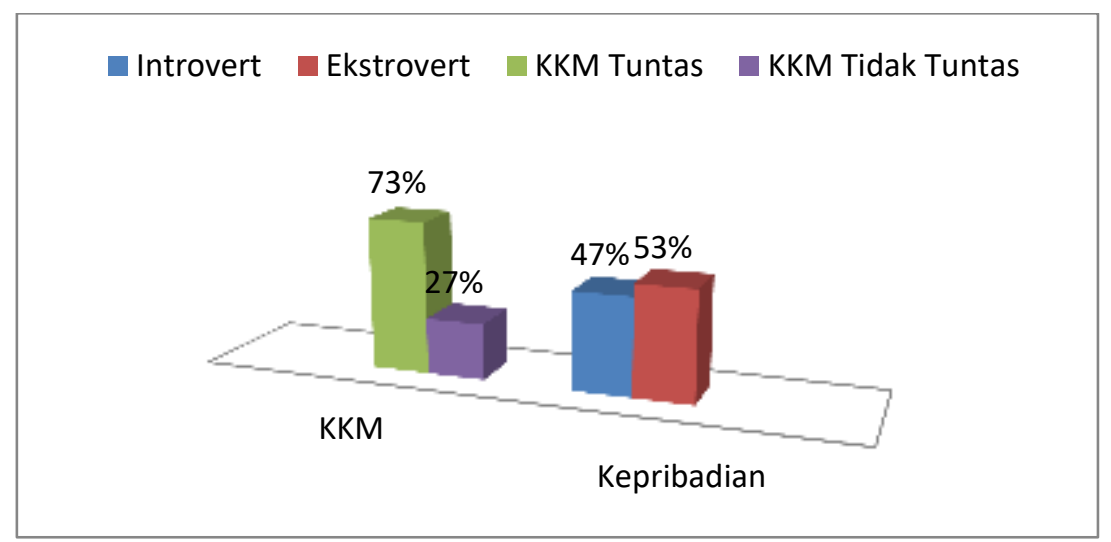

Gambar 5. Persentase Capaian KKM Siswa dengan Tipe Kepribadian Introvert dan Extrovert pada Siswa SMA N 6 Pulau Morotai

Berdasarkan perbandingan persentasi yang terdapat pada grafik diatas dapat disimpulkan bahwa hanya 4 siswa yang tidak dapat menuntaskan Kriteria Ketuntasan Minimum sedangkan 11 lainnya dapat menuntaskan KKM. Dilihat dari kegi kepribadian, siswa dengan kepribadian extrovert lebih mendominasi dibandingkan dengan siswa berkepribadian introvert dimana siswa dengan kepribadian extrovert berjuamlah 8 siswa dan 7 siswa lainnya memiliki tipe kepribadian introvert.

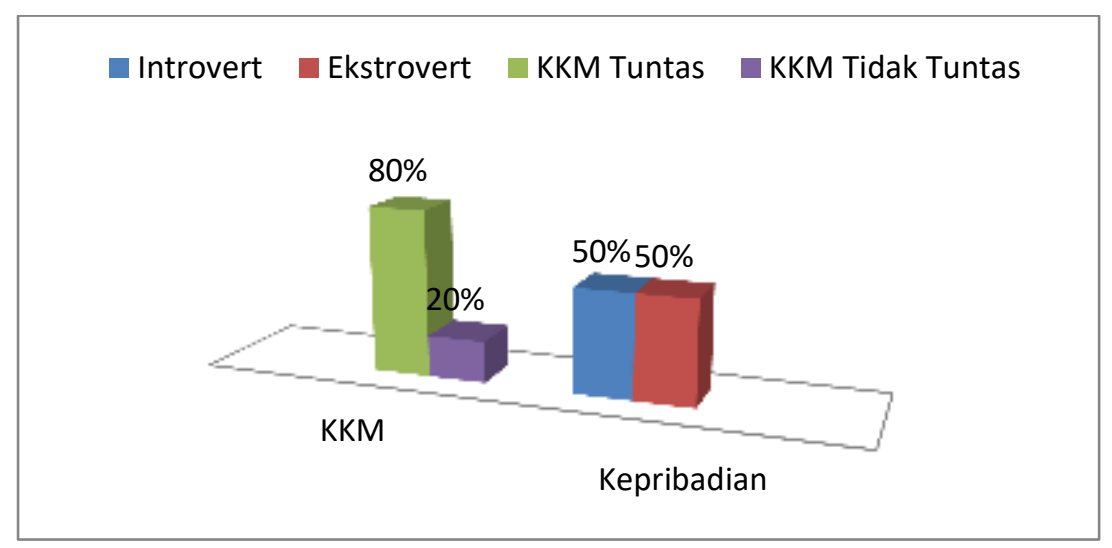

Gambar 16.Persentase Capaian KKM Siswa dengan Tipe Kepribadian Introvert dan Extrovert pada Siswa SMA M 3 Pulau Morotai

Gambar diatas memaparkan fakta bahwa dari 20 siswa secara keseluruhan, 4 siswa tidak dapat menuntaskan KKM, sedangkan dari segi kepribadian antara siswa 
yang memiliki kepribadian introvert sejajar dengan siswa yang memiliki kepribadian introvert.

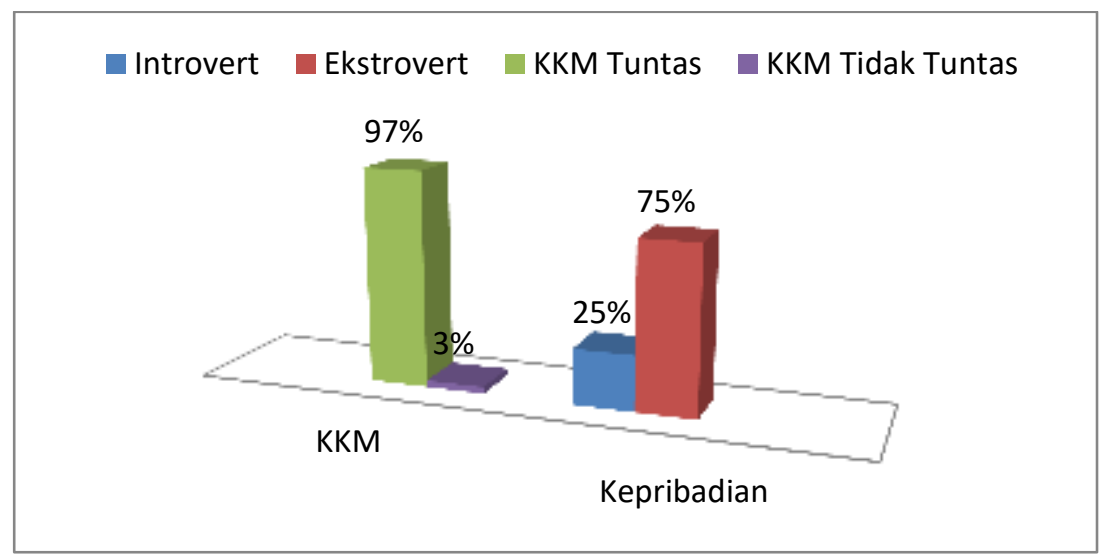

Gambar 7. Persentase Capaian KKM Siswa dengan Tipe Kepribadian Introvert dan Extrovert pada Siswa SMA M 4 Pulau Morotai

Ilustrasi diatas dapat diuraikan bahwa hampir keseluruhan siswa dapat mencapai KKM hanya 1 siswa yang tidak dapat mencapai KKM dari keseluruhan siswa yang berjumlah 33 siswa. Dari segi kepribadian, dapat dilihat bahwa yang mendominasi kepribadian dalam kelas adalah siswa dengan kepribadian extrovert sekitar 25 siswa sedangkan 8 siswa lainnya memiliki kepribadian introvert.

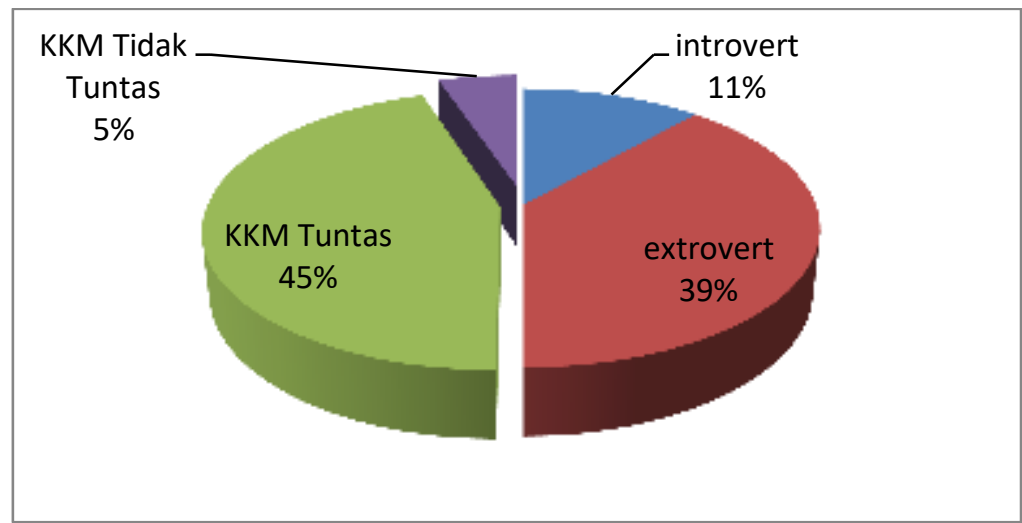

Gambar 8.Persentase Capaian KKM Siswa dengan Tipe Kepribadian Introvert dan Extrovert 
Pada gambar diatas, dapat disimpulkan bahwa siswa dengan kepribadian extrovert lebih dominan dibandingkan siswa dengan kepribadian introvert. Dimana 134 siswa memiliki tipe kepribadian extrovert dan 40 siswa lainnya berkepribadian introvert Berbeda halnya dengan capaian ketuntasan minimum yang dicapai oleh siswa, dimana dari 174 siswa hanya 18 siswa baik dari kepribadian introvert maun extrovert yang tidak dapat mencapai KKM.

Hasil KKM yang diperoleh menunjukkan bahwa rerata capaian KKM siswa pada mata pelajaran bahasa Inggris memenuhi standar minimum. Dimana dari 174 siswa terdapat 134 siswa yang memiliki kepribadian extrovert dan 14 siswa (10\%) tidak dapat menuntaskan KKM bahasa inggris. Sedangkan siswa dengan kepribadian introvert berjumlah 40 siswa dimana hanya 4 siswa (10\%) yang tidak dapat memenuhi standar KKM.

Siswa dengan kepribadian introvert maupun extrovert tidak memiliki perbedaan terhadap capaian hasil belajar pada mata pelajaran Bahasa Inggris. Meskipun pada penelitian yang dilakukan oleh Hamdani et.al (2013) menunjukkan bahwa terdapat hubungan yang positif antara kepribadian siswa dengan prestasi belajar dimana factor kepribadian memiliki pengaruh sebesar 20\%, keberhasilan lainnya disebabkan oleh factor lain. Sama halnya Penelitian lain yang dilakukan oleh Wijaya dan Indriana (2013) membuktikan bahwa minat belajar pada siswa dengan tendensi kepribadian Tipe A lebih tinggi daripada siswa dengan tendensi kepribadian Tipe B. Minat merupakan pendorong timbulnya motivasi dimana motivasi siswa adalah bagian penting dari keberhasilan dalam pendidikan. Akan tetapi hasil penelitian terbaru yang dilakukan di SMA yang tersebar di Kab Pulau Morotai menunjukkan bahwa Siswa dengan kepribadian introvert maupun extrovert dapat menuntaskan KKM dengan baik dan hanya $10 \%$ baik siswa dengan tipe kepribadian introvert maupun extrovert yang tidak dapat mencapai standar minimum KKM. Hal ini membuktikan bahwa siswa dengan tipe kepribadian introvert dan extrovert seimbang dalam pencapaian prestasi akademik. Hal ini tentunya kontras dengan apa 
yang diungkapkan Sukarno (2012: 11) bahwa seseorang dengan kepribadian tipe introvert lebih cenderung mengalami kegagalan dalam prestasi akademik dibandingkan dengan seseorang yang memiliki pepribadian extrovert, dikarenakan seseorang dengan tipe kepribadian extrovert tidak dapat membendung stress apabila tuntutan tugas dan waktu yang sangat tinggi di dunia pendidikan. Dimana stress dapat mempengaruhi minat belajar siswa hingga berujung pada baik atau buruknya prestasi akademik diperoleh siswa.

Meskipun Siswa dengan kepribadian introvert maupun extrovert tidak memiliki perbedaan terhadap capaian hasil belajar. Akan tetapi, perbedaan-perbedaan kepribadian yang dimiliki seseorang membawa implikasi terhadap cara guru mengelola proses pembelajaran bagi siswa di sekolah. Walaupun tidak mudah bagi guru memperhatikan perbedaan kepribadian secara detil dan menindaklanjuti dengan pembelajaran yang bersifat personal, namun perlu adanya usaha setiap guru untuk lebih memperhatikan perbedaan karakteristik dalam proses pembelajaran. Untuk itu seorang guru sebaiknya berusaha menemukan adanya perbedaan diantara siswanya sedini mungkin sehingga dapat menindak-lanjutinya dengan cepat (Sugiyanto, 2016:27). Faktor guru dan cara mengajarnya merupakan salah satu factor pendukung agar pembelajaran bahasa Inggris dapat berhasil. Bagaimana sikap dan kepribadian guru, tinggi rendahnya wawasan yang dimiliki guru dan bagaimana cara mentransfer ilmu pengetahuan kepada siswa turut menentukan prestasi akademik yang diraih siswa tersebut. (Amin dan Suardiman, 2016:13)

\section{SIMPULAN DAN SARAN}

Salah satu karakteristik penting dari pembelajaran yang efektif adalah ketika proses pembelajaran tersebut mampu merespon kebutuhan individual siswa. Memang terlalu banyak perbedaan yang ada diantara siswa sementara guru dituntut untuk dapat mengajar suatu materi dalam waktu yang sama. Namun demikian pembelajaran memerlukan sensitifitas terhadap perbedaan individual. Guru dapat membuat variasi metode, strategi, teknik maupun media dalam proses pembelajaran. Guru yang dapat mengakomodasi kebutuhan individual menunjukkan bahwa mereka ingin merangkul seluruh siswa dalam seluruh proses pembelajaran. Selanjutnya siswa memiliki kemungkinan yang lebih besar untuk aktif berpartisipasi dalam kelas ketika mereka tahu bahwa guru mereka mempertimbangkan kebutuhan mereka sebagai individu. Hasil penelitian ini diharapkan menjadi bahan masukan terhadap para guru di Kabupaten Pulau Morotai serda Dinas Pendidikan setempat. Perlu adanya perhatian 
khusus pada mata pelajaran bahasa Inggris dikarenakan hasil penelitan menunjukkan $10 \%$ siswa dengan tipe kepribadian introvert maupun extrovert belum mampu mencapai criteria minimum KKM mata pelajaran bahasa inggris. Selain itu, perlu adanya inovasi dan kreatifitas mengajar yang dilakukan oleh guru-guru di Kab Pulau Morotai khususnya dalam pengajaran mata pelajaran Bahasa Inggris yang bertujuan guna peningkatan kecakapan berbahasa Inggris. 


\section{Daftar Pustaka}

Amin, Alima dan Suardiman, P. Siti. 2016. Perbedaan Prestasi Belajar Matematika Siswa Ditinjau dari Gaya Belajar dan Model Pembelajaran. Jurnal Prima Edukasia Vol 4 No,1 Januari 2016. Yogyakarta: Universitas Ahmad Dahlan.

Azwar,S. 2008. Dasar-Dasar Psikometri. Yogyakarta: Pustaka Belajar.

Baharuddin. 2012. Psikologi Pendidikan: Refleksi Teoritis Terhadap Fenomena. Jogjakarta: ArRuzz Media.

Dimitru. 2012. The Relationship Between Stress and Personality Factors. Human and Veterinary Medicine. International Journal of The Bioflux Society Volume 4 No.1. Romania : University of Medicine and Pharmacy Cluj-Napoca.

Feist, J \& Feist, G.J. 2010. Teori Kepribadian. Jakarta: Salemba Humanica.

Hamdani. Ulfa, Maria dan Syahrudin, Husni. 2013. Hubungan Kepribadian dengan Prestasi Belajar Siswa Kelas IX pada Mata Pelajaran IPS Terpadu. Pontianak: UNTAN.

Hawari, D. 2008. Manajemen Stres Cemas dan Depresi . Jakarta : Balai Penerbit FK UI. Lusiana, Maresa. Risina Devi dan Lesmana D Suri. 2009. Hubungan Tipe Kepribadian dengan Prestasi Akademik pada Mahasiswa Fakultas Kedokteran Universitas Riau Angkatan 2006. Jurnal Ilmu Kedokteran (JIK).Jilid 3. Nomor 1, Maret 2009.

Nilawati, Levi dan Bimo, L. Dwinanto. 2010. Pengaruh Motivasi pada Kinerja Belajar. Pengujian Terhadap Sebuah Model. Jurnal Manajemen Bisnis. Vol 3. No 3. Desember 2010-Maret 2011(287-303). Jakarta: Universitas Katolik Atma Jaya Jakarta.

Nur Maziyah Ulya. 2016. Pengaruh Metode Pembelajaran dan Tipe Kepribadian Terhadap Hasil Belajar Bahasa Arab (Studi Eksperimen Pada MAN 1 Semarang). Jurnal Pendidikan Islam. ISSN 1979-1739. Vol. 10. Nomor 1. April 2016. Semarang: UIN Walisongo.

Sugiyanto.2016.Psikologi Pendidikan; Perbedaan Individual, Program Studi Bimbingan dan Konseling Fakultas Ilmu Pendidikan. Yogyakarta: Universitas Negeri Yogyakarta.

Sukarno, G. 2012. Stress Kerja Aparatur Pemerintah Kantor inspektorat Kabupaten Tulungagung Sebagai Dampak Kepribadian type A dan Peran.Journal Lib Unair, Vol 22, No 2. Surabaya: Universitas Airlangga.

Widiantari, S. Komang dan Herdiyanto, K. Yohanes. 2013. Perbedaan Intensitas Komunikasi Melalui Jejaring Social Antara Tipe Kepribadian Extrovert Dan Introvert Pada Remaja. Jurnal Psikologi Udayana. Vol.1 No. 1 10-115. ISSN: 2354-5607. Bali: Universitas Udayana.

Wijaya, A. Zainuddin dan Indriana,Yeniar.2013. Perbedaan Minat Belajar Ditinjau dari Tendensi Kepribadian Tipe A dan Tipe B pada Siswa Kelas XI SMA N 10 Semarang. Semarang.

Yusuf, S dan Nurihsan, J. 2007. Teori Kepribadian. Bandung: PT Remaja Rosdakarya. 